\title{
Steam gasification reactivity of a high-sodium coal fly ash obtained from a pilot scale CFB gasifier
}

\author{
Haixia Zhang ${ }^{1} \cdot$ Kuangshi Yu ${ }^{1} \cdot$ Zhiping Zhu ${ }^{1}$
}

Received: 10 September 2017/Revised: 26 December 2017/Accepted: 8 January 2018/Published online: 22 January 2018

(C) The Author(s) 2018. This article is an open access publication

\begin{abstract}
Circulating fluidized bed (CFB) gasification has several advantages for the utilization of low rank coals. However, the carbon content of fly ash is usually very high, which greatly influences the gasification efficiency. The purpose of this research is to investigate the gasification reactivity of a high-sodium Zhundong (ZD) coal fly ash obtained from a pilot-scale $2.5 \mathrm{t} / \mathrm{d}$ CFB gasification system. The experiments were carried out in a thermogravimetric analyzer with steam as gasification agent, and fast pyrolyzed ZD char was also investigated as a reference sample. The results show that increasing temperature accelerates the gasification rate both for fly ash and ZD char. Fly ash has higher gasification rate at the initial gasification stage. On the contrary, ZD char has higher reaction rate even at higher carbon conversion stage. Via distributed activation energy model, the average activation energy of ZD char and fly ash is calculated to be 94.4 and $91.2 \mathrm{~kJ} / \mathrm{mol}$, respectively. The integrated model study reveals that the reaction order of ZD char is about 0.74 , whereas the reaction order of fly ash decreases from 1 to 0.59 when temperature increases from 900 to $1050{ }^{\circ} \mathrm{C}$. The gasification reactivity of ZD coal fly ash is quite different with literature research on those fly ashes with rarely little catalytic elements in coal ashes. The interesting results are related with the unique properties of ZD coal fly ash and the transformation of sodium during gasification process.
\end{abstract}

Keywords Fly ash · High sodium coal · Gasification · CFB · TGA

\section{Introduction}

Zhundong (ZD) coalfield is the largest integrated coal basin newly found in Xinjiang of China. Owing to the large coal reserves (1.64 Gt) (Zhou et al. 2010) and unique properties (such as high volatile content, low ash content, low sulfur content and high reactivity) (Zhang et al. 2015b), the utilization of ZD coal has become a research focus in recent years. Gasification is a clean and more efficient coal conversion technology (Li 2013). Among various gasification technologies, circulating fluidized bed (CFB) gasification has been recognized as a promising technology due to its

Haixia Zhang

zhanghaixia@iet.cn

1 Institute of Engineering Thermophysics, Chinese Academy of Sciences, Beijing 100190, China low emission of pollutants, wide fuels adaptability, low production cost, and so on (Zhang et al. 2013; Liu et al. 2015; Zhang et al. 2017b). Unfortunately, the carbon content of coal fly ash is usually quite high (Kelebopile et al. 2011), which is considered as the major determinant of gasification efficiency. Some research has been carried out to study the properties and management of coal fly ash (Chugh and Behum 2014; Tsadilas et al. 2014; Wang and Song 2016). However, the high efficient utilization of coal gasification fly ash is still a great challenge and has not been sufficiently investigated yet.

Coal gasification could be classified as pyrolysis step and the generated char gasification step, and the gasification step is a step of rate limiting. Irfan et al. (2011) reviewed coal gasification with $\mathrm{CO}_{2}$ as gasification agent, and obtained that the most used reactor is thermogravimetric analyzer (TGA). Fu and Wang (2001) obtained kinetics parameters of char- $\mathrm{CO}_{2}$ gasification and 
Table 1 Proximate and ultimate analyses of samples

\begin{tabular}{|c|c|c|c|c|c|c|c|c|c|c|c|}
\hline \multirow[t]{2}{*}{ Sample } & \multicolumn{4}{|c|}{ Proximate analysis (wt/\%) } & \multicolumn{6}{|c|}{ Ultimate analysis (wt/\%) } & \multirow{2}{*}{$\begin{array}{l}\text { Net calorific value }(\mathrm{MJ} / \mathrm{kg}) \\
\mathrm{LHV}_{\mathrm{ar}}\end{array}$} \\
\hline & $M_{\mathrm{ad}}$ & $A_{\text {ad }}$ & $V_{\text {ad }}$ & $\mathrm{FC}_{\mathrm{ad}}$ & $\mathrm{C}_{\mathrm{ad}}$ & $\mathrm{H}_{\mathrm{ad}}$ & $\mathrm{O}_{\mathrm{ad}}$ & $\mathrm{S}_{\mathrm{ad}}$ & $\mathrm{N}_{\mathrm{ad}}$ & $\mathrm{Cl}_{\mathrm{ad}}$ & \\
\hline ZD coal & 14.32 & 8.18 & 26.77 & 51.73 & 61.64 & 3.03 & 11.39 & 1.00 & 0.62 & 0.625 & 22.92 \\
\hline Fly ash & 5.69 & 21.62 & 6.22 & 66.47 & 66.06 & 0.68 & 3.22 & 2.21 & 0.52 & 3.468 & 23.40 \\
\hline ZD char & 4.87 & 17.00 & 4.49 & 73.64 & 74.14 & 0.90 & 0.98 & 1.55 & 0.56 & 0.660 & 26.39 \\
\hline
\end{tabular}

$a d$ air dry basis, $F C$ fixed carbon, $V$ volatile matter, $A$ ash, $M$ moisture

Table 2 Ash composition of ZD coal (wt/\%)

\begin{tabular}{llllllllllll}
\hline Sample & $\mathrm{SiO}_{2}$ & $\mathrm{Al}_{2} \mathrm{O}_{3}$ & $\mathrm{Fe}_{2} \mathrm{O}_{3}$ & $\mathrm{CaO}$ & $\mathrm{MgO}$ & $\mathrm{TiO}_{2}$ & $\mathrm{SO}_{3}$ & $\mathrm{P}_{2} \mathrm{O}_{5}$ & $\mathrm{~K}_{2} \mathrm{O}$ & $\mathrm{Na}_{2} \mathrm{O}$ \\
\hline ZD coal & 23.28 & 9.26 & 18.26 & 10.95 & 2.72 & 0.54 & 18.58 & 0.54 & 0.86 & 7.86 \\
\hline
\end{tabular}

Table 3 Ash fusibility characteristics of ZD coal

\begin{tabular}{lllll}
\hline Sample & \multicolumn{4}{l}{ Ash fusion temperature $t\left({ }^{\circ} \mathrm{C}\right)$} \\
\cline { 2 - 5 } & DT & ST & HT & FT \\
\hline ZD coal & 1030 & 1060 & 1080 & 1100 \\
\hline
\end{tabular}

$D T$ deformation temperature; $S T$ soften temperature; $H T$ hemisphere temperature; $F T$ flow temperature

investigated the relationship between kinetics parameters and coal types.

The alkali content (mainly sodium) in ZD coal ash is quite high (2\%-10\%). The high-sodium content in coal ash may cause fouling and slagging problems, influencing the operation safety of units (Jin et al. 2015; Wang et al. 2015; Fan et al. 2016; Song et al. 2016a; Zhang et al. 2017a). During the thermal utilization process, sodium transforms with the conversion of coal, and the properties of the derived fly ash may be different with other coal fly ashes. Zhang et al. (2017c) investigated properties and $\mathrm{CO}_{2}$ gasification reactivity of ZD coal fly ash with a TGA. The used fly ash is obtained from a lab-scale fluidized bed test rig. Mi et al. (2015) studied the catalytic effects of AAEM (alkali and alkaline earth metallic species) on char gasification, and obtained that sodium content and carbon structure are the main parameters influencing char reactivity in steam and oxygen atmosphere.

To date, a large body of useful data in the area of coal or char gasification has been delivered, regarding both the experiments and kinetics study (Everson et al. 2006; Fan et al. 2007; Irfan et al. 2011, 2012; Li et al. 2014; Liu et al. 2015). However, rarely little research has been conducted to investigate the gasification reactivity of high-sodium coal fly ash obtained from large scale CFB gasifier.
The aim of this study is to investigate the gasification reactivity of a high-sodium ZD coal fly ash, which was produced by a $2.5 \mathrm{t} / \mathrm{d}$ CFB gasification system with a highsodium ZD coal as feedstock. The experiments were carried out in a TGA analyzer with steam as gasification agent, and the results were compared with fast pyrolyzed ZD char. The samples were analyzed with X-ray diffraction (XRD), scanning electron microscope (SEM), specific surface area and pore property. Distributed activation energy model (DAEM) and integrated model were used to fit the kinetics data.

\section{Experimental}

\subsection{Fuel characteristics}

The used fly ash was a by-product of a $2.5 \mathrm{t} / \mathrm{d}$ CFB gasification system, which uses ZD coal as feed stock. The ZD coal was obtained from MuLei of Xinjiang, China. Table 1 shows the proximate and ultimate analyses of ZD coal and fly ash. Tables 2 and 3 show the ash composition and the ash fusibility characteristics of ZD coal, respectively. The $\mathrm{Na}_{2} \mathrm{O}$ content in ZD coal ash is up to $7.86 \%$. The samples were analyzed according to the Chinese standards of $\mathrm{GB} /$ T212-2008, GB/T 476-2008, GB/T 19227-2008, GB/T 214-2007, GB/T 3558-2014, GB/T 213-2008, GB/T 1574-2007 and GB/T 219-2008. At least three sets of runs were repeated for the specific sample, good reproducibility and accuracy of analyzing results were obtained.

\subsection{CFB gasification system and fly ash acquisition}

The schematic diagram of the CFB test rig is shown in Fig. 1, which is a pilot-scale dual-bed CFB gasification 


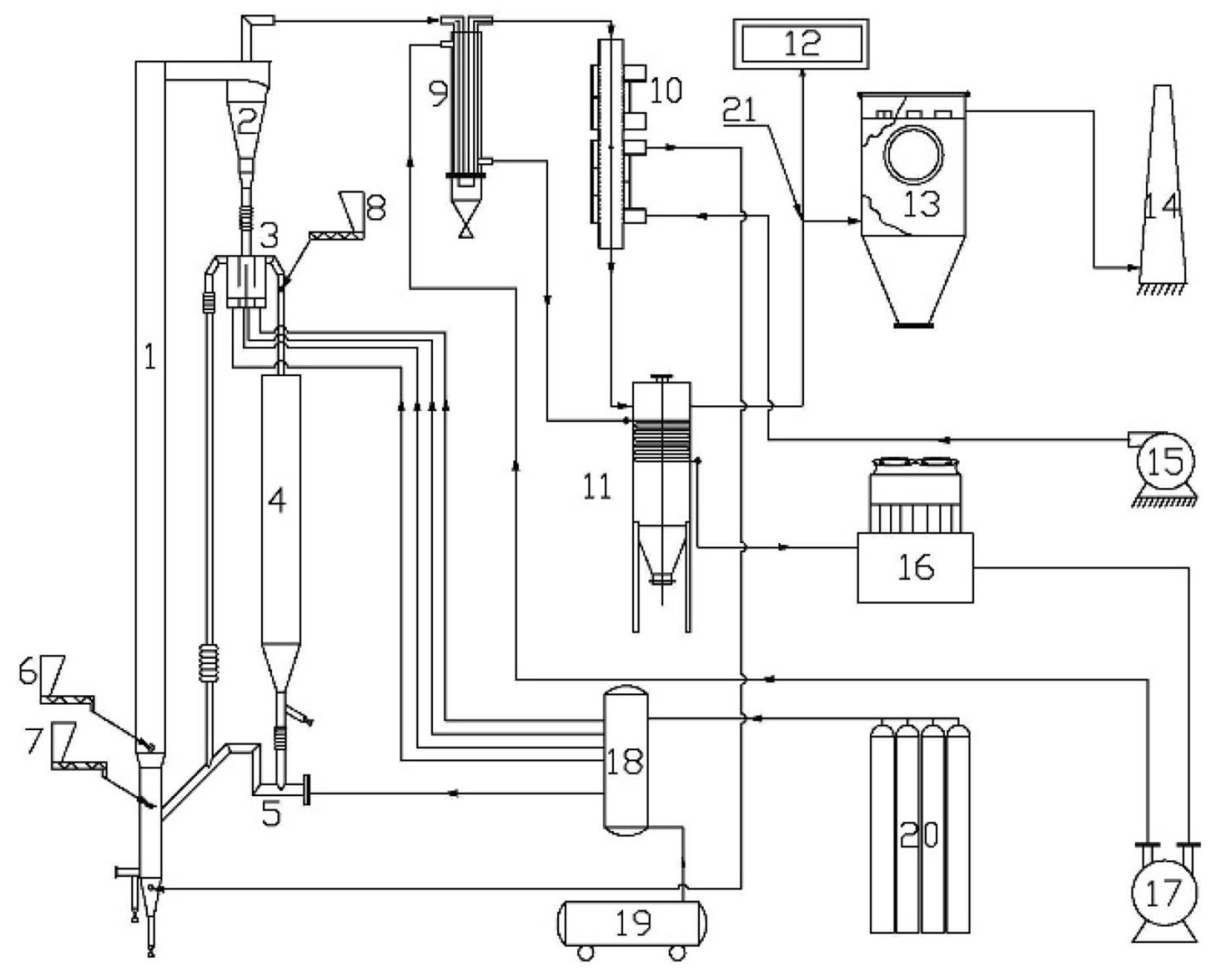

Fig. 1 Schematic diagram of the test rig (Yu 2012). 1-gasifier; 2-cyclone; 3-upper loop seal; 4-pyrolyzer; 5-lower loop seal; 6-screw feeder I; 7-screw feeder II; 8-screw feeder III; 9-water cooler; 10-air preheater; 11-inertial separator; 12-gas analyzer; 13-bag filter; 14-chimney; 15-blower; 16-water tower; 17—water bump; 18-gas tank; 19-air compressor; 20— $\mathrm{N}_{2}$ cylinder; 21—gas sampling port

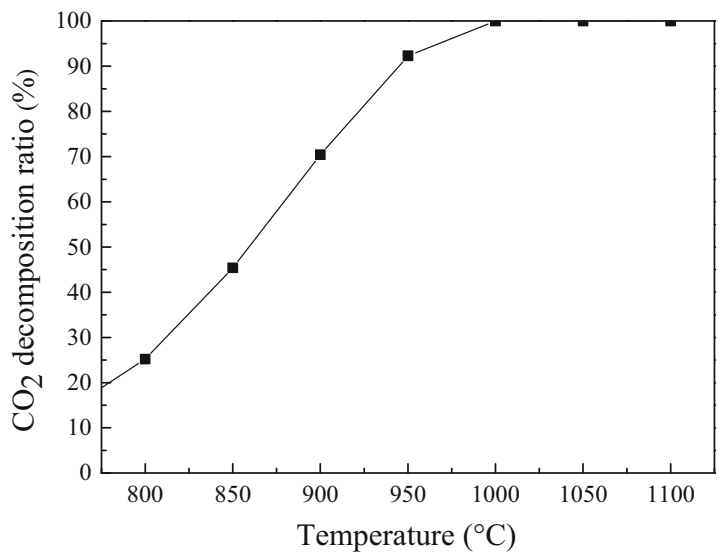

Fig. $2 \mathrm{CO}_{2}$ gasification reactivity of $\mathrm{ZD}$ coal

system with a maximum coal-feeding rate about $2.5 \mathrm{t} / \mathrm{d}$. Particularly, single-bed CFB gasification or dual-bed CFB pyrolysis coupled with gasification could be easily operated, respectively. In this study, single bed CFB gasification system was selected to conduct ZD coal gasification. Air was used as gasification agent. During the gasification process, the flow rate of air was fixed at $170 \mathrm{~N} \mathrm{~m}^{3} / \mathrm{h}$, and the coal feeding rate was tuned to achieve different gasification temperature levels.

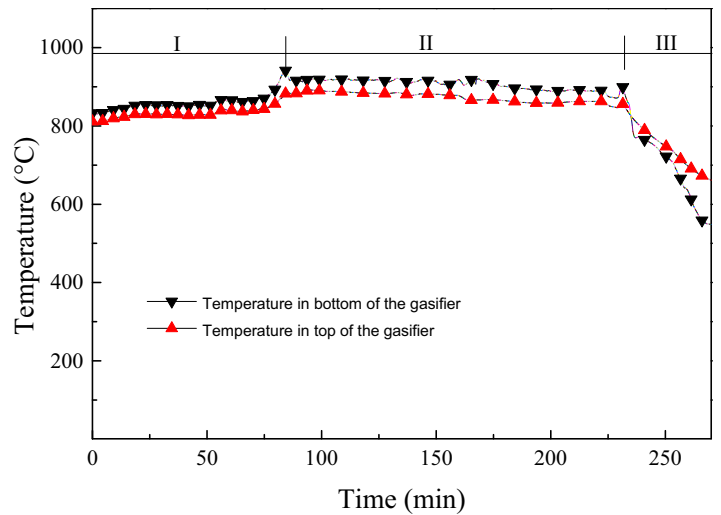

Fig. 3 Temperature profiles of CFB gasification

Figure 2 shows the $\mathrm{CO}_{2}$ decomposition ratio of $\mathrm{ZD}$ coal. The $\mathrm{CO}_{2}$ decomposition ratio is $45.4 \%$ at gasification temperature of $850{ }^{\circ} \mathrm{C}$. Increasing the temperature to 900 and $950{ }^{\circ} \mathrm{C}$, the $\mathrm{CO}_{2}$ decomposition ratio increases to $70.4 \%$ and $92.3 \%$, respectively. The results indicate that temperature has great influence on ZD coal gasification reactivity, especially in CFB operating temperature ranges $\left(850-950{ }^{\circ} \mathrm{C}\right)$. In order to reduce the agglomeration risk of high sodium coal gasification, lower bed temperature was controlled during the initial gasification stage, and then the bed temperature was elevated via adjusting the coal feeding 
speed. Figure 3 presents the gasification temperatures of the gasifier. In stage I, the air/coal ratio is set at $1.90 \mathrm{Nm}^{3} /$ $\mathrm{kg}$, and the temperature in the bottom of the gasifier is about $880{ }^{\circ} \mathrm{C}$. In stage II, the air/coal ratio is increased to $2.07 \mathrm{Nm}^{3} / \mathrm{kg}$, and the temperature in the bottom of the gasifier is about $930{ }^{\circ} \mathrm{C}$. It can be seen from Fig. 3 that the gasifier runs stable at different temperature levels. The used fly ash was obtained from the gas sampling point during gasification stage II.

\subsection{Fast pyrolyzed char preparation}

In order to evaluate the gasification performance of fly ash, fast pyrolyzed ZD char was prepared and used as reference sample. The pyrolysis experiments were conducted in a horizontal tube reactor using $0.18-0.355 \mathrm{~mm}$ ZD coal. The schematic and operation details have been described in literature (Zhang et al. 2017c). Briefly, ZD coal was hold at $900{ }^{\circ} \mathrm{C}$ for 5 min with $\mathrm{N}_{2}$ as carrier gas. When temperature was cooled to room temperature, ZD char sample was collected. The proximate and ultimate analyses of ZD char were also shown in Table 1.

\subsection{Thermogravimetric analysis}

Steam isothermal gasification experiments were conducted in a Netzsch STA-449F3 analyzer. The gasification temperatures were set at 900, 950, 1000 and $1050{ }^{\circ} \mathrm{C}$, respectively. For each run, about $15 \mathrm{mg}$ of sample was used. The sample was placed in an alumina crucible and heated up at $10^{\circ} \mathrm{C} / \mathrm{min}$ with $150 \mathrm{~mL} / \mathrm{min}$ of $\mathrm{Ar}$ as carrier gas. When the temperature achieved the set value and stayed for $5 \mathrm{~min}$, Ar was decreased to $20 \mathrm{~mL} / \mathrm{min}$ and $3 \mathrm{~g} /$ $\mathrm{h}$ of steam was introduced simultaneously. The isothermal gasification experiment lasted for $1 \mathrm{~h}$. At the end stage of each experiment, a small amount of $\mathrm{O}_{2}$ was added to burn out the unreacted carbon. The values of carbon conversion $(x)$ and specific rate $(r)$ are calculated according to Eqs. (1) and (2), respectively.

$x=\frac{\Delta m}{m_{0}\left(1-A_{\mathrm{d}}-V_{\mathrm{d}}\right)}$

$r=\frac{1}{1-x} \frac{\mathrm{d} x}{\mathrm{~d} t}$

where $x$ represents the carbon conversion, $\Delta m$ represents the mass loss of sample, $m_{0}$ represents the initial mass of the sample, $A_{\mathrm{d}}$ represents the mass of ash, $V_{\mathrm{d}}$ represents the mass of volatile, $\mathrm{d} x / \mathrm{d} t$ is the reaction rate, $r$ is the specific rate, and $t$ represents the reaction time.

\subsection{Sample characterizations}

Sample morphologies were observed via a scanning electron microscope (SEM, JSM-6360LV). The specific surface area and the pore property of samples were analyzed via $\mathrm{CO}_{2}$ isothermal measurements (Tristar II $3020 \mathrm{M}$ ). $\mathrm{X}$-ray diffraction (XRD) characterization was performed (Rigaku D/max 2500) to detect phase changes of samples. Inductively coupled plasma optical emission spectrometry (ICP-OES, Model IRIS Intrepid II XSP) was used to analysis the ash compositions of samples. The chlorine content in ZD char and fly ash was detected via X-ray fluorescence (XRF) using AXIOS (PANalytical). Laser diffractometer (Malvern; ZETASIZER-3000HS) was used to analyze the particle size distribution of fly ash. The $\mathrm{CO}_{2}$ decomposition ratio of $\mathrm{ZD}$ coal is analyzed according to Chinese standard GB/T 220-2001.

\section{Results and discussion}

\subsection{Physical properties of samples}

Figure 4 shows the SEM images of ZD char and ZD coal fly ash. From Fig. 4a we can see that ZD char shows rough particle structure, and there are some holes and fragments on the surface of char particles. This phenomenon could be
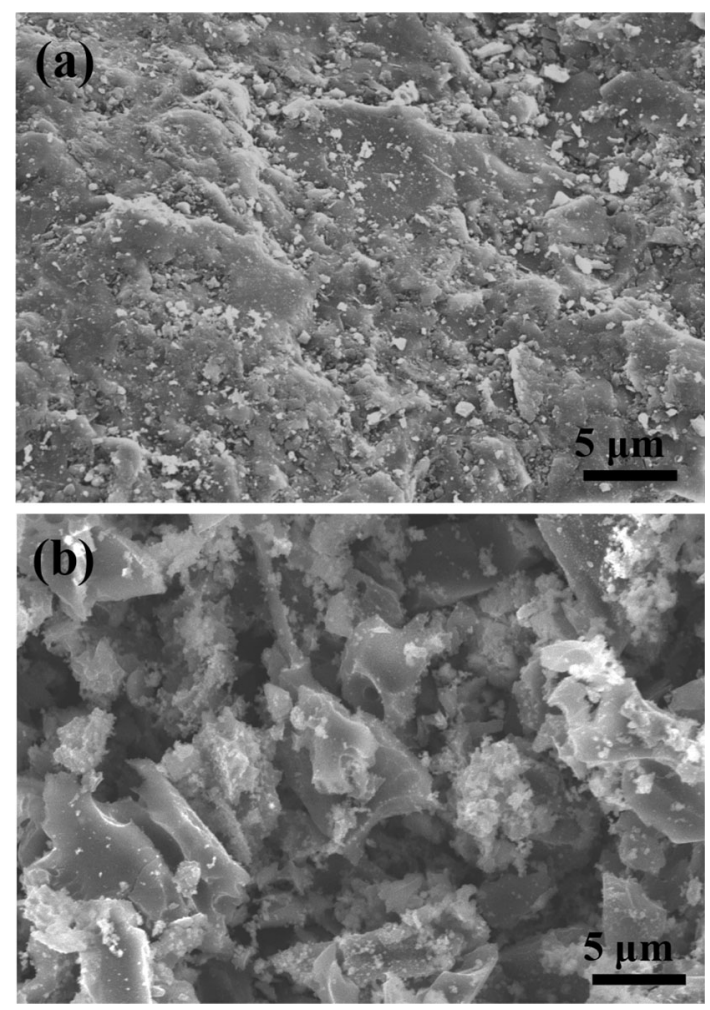

Fig. 4 SEM images of ZD char (a) and fly ash (b) 


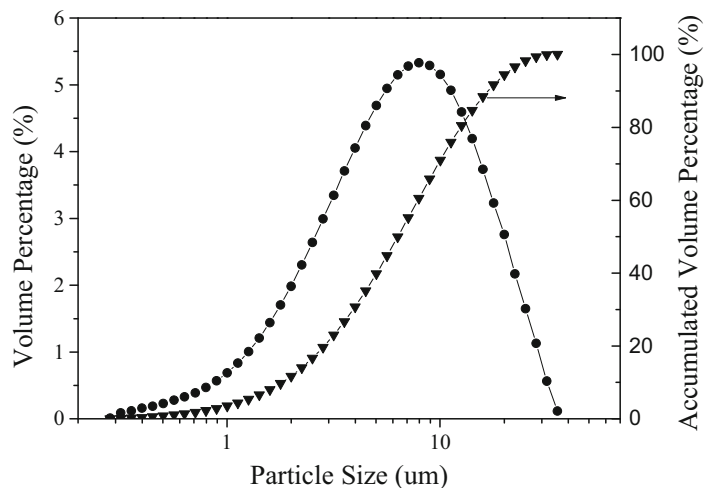

Fig. 5 Particle size distribution of fly ash

Table 4 Pore structure parameters of ZD char and fly ash

\begin{tabular}{llll}
\hline Sample & $\begin{array}{l}\text { Pore size } \\
(\mathrm{nm})\end{array}$ & $\begin{array}{l}\text { Total pore volume } \\
(\mathrm{cc} / \mathrm{g})\end{array}$ & $\begin{array}{l}\text { Langmuir surface area } \\
\left(\mathrm{m}^{2} / \mathrm{g}\right)\end{array}$ \\
\hline $\begin{array}{r}\text { ZD } \\
\text { char }\end{array}$ & 13.18 & 0.088 & 227.6 \\
$\begin{array}{l}\text { Fly ash } \\
\text { Fly }\end{array}$ & 1.58 & 0.043 & 80.7 \\
\hline
\end{tabular}

ascribed to the volatilization of volatiles during pyrolysis process of ZD coal. By comparison, the fly ash shows more rough particle surface, and was composed of some small particles. The particle size distribution of fly ash is presented in Fig. 5. The $d_{50}$ of fly ash is about $7.1 \mathrm{um}$, and $d_{90}$ is about $18.8 \mathrm{um}$. The particle size of fly ash is quite small, and this is in accordance with the SEM image as shown in Fig. 4b. It is worth mentioning that the particle size of ZD coal fly ash used in this study is much smaller than the fly ashes obtained from a $240 \mathrm{t} / \mathrm{d}$ of industrial CFB gasifier, which used Shigouyi low-rank coal as feedstock (Zhang et al. 2013). The particle size of fly ash is related with several factors, such as coal properties, thermal stability, ash compositions, gasification conditions and structure properties of gasifier. Pore structure parameters and specific surface area of samples are shown in Table 4. Although the fly ash has smaller particle size and smaller pore size, the specific surface area of fly ash is lower than ZD char. These properties would be discussed further in Sects. 3.2 and 3.3.

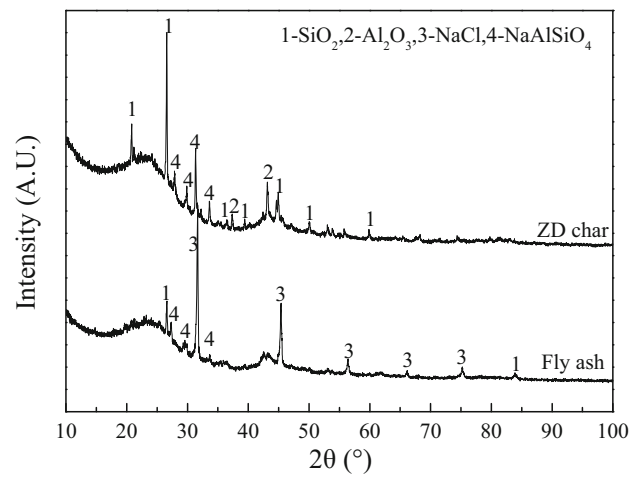

Fig. 6 XRD patterns of ZD char and fly ash

The XRD patterns of fly ash and ZD char are compared in Fig. 6. There are two wide bands both for fly ash and ZD char. The wide bands around $2 \theta \approx 25^{\circ}$ and $44^{\circ}$ represent the parallel orientation and the size of aromatic, respectively. There is no obvious difference between fly ash and ZD char on these two bands, indicating similar graphitic microcrystalline of the two samples. However, $\mathrm{NaCl}$ is observed in fly ash. The presence of $\mathrm{NaCl}$ could be attributed to the volatilization of sodium/chlorine-containing species (or $\mathrm{NaCl}$ ), and also could be attributed to the reactions between sodium-containing and chlorine-containing species during $\mathrm{ZD}$ coal gasification process. $\mathrm{NaAlSiO}_{4}$ is detected in ZD char and fly ash, which could be formed according to Eq. (3). $\mathrm{NaAlSiO}_{4}$ is a high-melting-point Na-containing compound with melting point of about $1550{ }^{\circ} \mathrm{C}$. The presence of $\mathrm{NaAlSiO}_{4}$ in $\mathrm{ZD}$ char is helpful to inhibit agglomeration (Zhang et al. 2017a).

$\mathrm{Na}_{2} \mathrm{O}+\mathrm{Al}_{2} \mathrm{O}_{3}+2 \mathrm{SiO}_{2} \rightarrow 2 \mathrm{NaAlSiO}_{4}$

Table 5 compares the ash compositions of fly ash and ZD char. The $\mathrm{Na}_{2} \mathrm{O}$ content and chlorine content in fly ash are higher than ZD char. The results confirmed the concentration of chlorine and sodium in fly ash, which are related with the easily volatilization property of sodiumcontaining and chlorine-containing species. During CFB gasification process, some sodium and chlorine would release to gas phase, and leave gasifier with the flow of the produced fuel gas. At the subsequent process, the sodiumcontaining and chlorine-containing species would condense or adhere to the surface of fly ash, and correspondingly increase the chlorine content and sodium content in fly ash. Probably due to the higher chlorine and sodium contents,

Table 5 Ash compositions of ZD char and fly ash

\begin{tabular}{llllllllllll}
\hline Sample & $\mathrm{SiO}_{2}$ & $\mathrm{Al}_{2} \mathrm{O}_{3}$ & $\mathrm{Fe}_{2} \mathrm{O}_{3}$ & $\mathrm{CaO}$ & $\mathrm{MgO}$ & $\mathrm{TiO}_{2}$ & $\mathrm{SO}_{3}$ & $\mathrm{P}_{2} \mathrm{O}_{5}$ & $\mathrm{~K}_{2} \mathrm{O}$ & $\mathrm{Na}_{2} \mathrm{O}$ & $\mathrm{Cl}$ \\
\hline ZD char & 18.81 & 6.17 & 10.74 & 15.42 & 2.13 & 0.78 & 29.87 & 0.46 & 0.99 & 6.14 & 8.28 \\
Fly ash & 14.92 & 9.02 & 8.80 & 11.05 & 3.15 & 0.75 & 24.41 & 0.45 & 2.47 & 7.20 & 17.38 \\
\hline
\end{tabular}



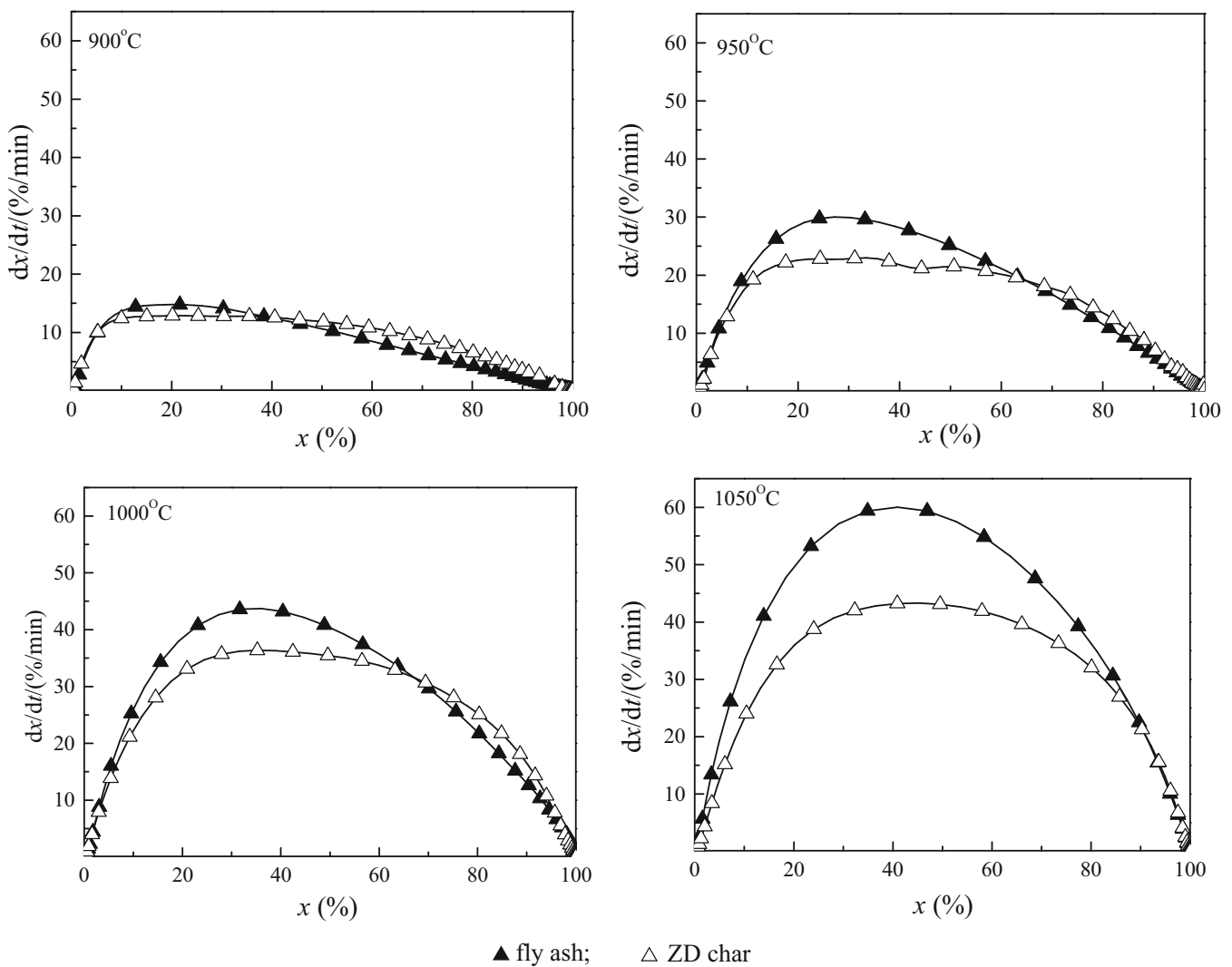

Fig. 7 Gasification reaction rate at different temperatures

$\mathrm{NaCl}$ was detected in fly ash as presented in Fig. 6. Zhang et al. (2017a) conducted fluidized bed gasification of another type of ZD coal, and obtained that the content of chlorine in fly ash is higher than in bottom char. Song et al. (2016b) conducted CFB gasification of a medium sodium content $\mathrm{ZD}$ coal, and the results indicate that $\mathrm{NaCl}$ and $\mathrm{NaAlSiO}_{4}$ are detected in fly ash, and $\mathrm{NaAlSiO}_{4}$ is the main sodium-containing compound in bottom char. The results obtained in this study is in accordance with the literature. Chlorine is easy to release and concentrate on surface of fly ash. Table 5 also shows that the content of chlorine is much higher than sodium. The results reveal that the release of chlorine and sodium is not proportional, and this is similar with the results obtained by Quyn et al. (2002) and Kosminski et al. (2006).

\subsection{Gasification reactivity of samples}

Figure 7 shows the variation of gasification reaction rate versus carbon conversion. At different gasification temperatures, the curves show similar varying trend both for fly ash and ZD char. The reaction rate increases obviously with the carbon conversion at the initial gasification period, and then decreases slightly. There is a maximum reaction rate during the gasification process, and the value moves to the higher carbon conversion with the increase of gasification temperature. For each experiment, the reaction rate of fly ash is higher than that of ZD char in the initial period of gasification, which could be ascribed to the smaller particle size, the smaller pore diameter and the higher sodium content of fly ash. It is recognized that sodium has catalytic effect on carbon conversion. For steam gasification, sodium could react with steam to form $\mathrm{NaOH}$ according to Eq. (4), and then to form $\mathrm{Na}_{2} \mathrm{CO}_{3}$ according to Eq. (5) (Kosminski et al. 2006). $\mathrm{Na}_{2} \mathrm{CO}_{3}$ can further react with carbon, as shown in Eq. (6), and thereby influence the gasification reactivity of sample. By comparison, ZD char has higher reaction rate even at higher carbon conversion. As shown in Table 5, some sodium was also retained in ZD char matrix after pyrolysis process. However, the volatilization property of the retained sodium species is usually very low. The higher reaction rate of ZD char at higher carbon conversion stage could be ascribed to the higher surface area of $\mathrm{ZD}$ char, the evolution of microstructure and reaction sites of char during gasification procedure.

According to literature, the gasification reactivity of fly ashes, produced by a $240 \mathrm{t} / \mathrm{d}$ industrial CFB gasifier using Shigouyi coal as feedstock (Zhang et al. 2013) or produced by a $5 \mathrm{t} / \mathrm{d}$ pilot scale CFB gasifier using Shenmu coal as 
feedstock (Zhang et al. 2015a), is better than the raw coal chars, respectively. There are rarely little catalytic species in Shigouyi coal ash and Shenmu coal ash. The interesting gasification reactivity of ZD coal fly ash obtained in this study could be due to the transformation of sodium species during CFB gasification process and the further transformation during TGA steam gasification process. Zhang and Zhang (2017) studied the gasification reactivity of Shigouyi coal and a high sodium ZD coal via TGA. The results indicate the $\mathrm{ZD}$ coal has lower activation energy and shows better gasification reactivity than Shigouyi coal.

$$
\begin{aligned}
& 2 \mathrm{Na}+2 \mathrm{H}_{2} \mathrm{O} \rightarrow 2 \mathrm{NaOH}+\mathrm{H}_{2} \\
& 2 \mathrm{NaOH}+\mathrm{CO} \rightarrow \mathrm{Na}_{2} \mathrm{CO}_{3}+\mathrm{H}_{2} \\
& \mathrm{Na}_{2} \mathrm{CO}_{3}+2 \mathrm{C} \rightarrow 2 \mathrm{Na}+3 \mathrm{CO}
\end{aligned}
$$

\subsection{Kinetics analysis}

Many gasification kinetics models have been reported to describe coal gasification (Irfan et al. 2012; Gonzalo-Tirado et al. 2013; Duan et al. 2016; Zhang and Zhang 2017). In recent years, some work has been done to study the gasification kinetics of fly ash (Kelebopile et al. 2011). However, the research is not sufficient and much work needs to be carried out. In this study, we used DAEM and integrated model to fit the kinetics data of ZD char and fly ash.

DAEM model could be described as follows (Zhang and Zhang 2017):

$\ln t=-\ln k_{0}+\ln \left[\frac{1-(1-x)^{1-n}}{1-n}\right]+\frac{E}{R} \frac{1}{T}$

where $k_{0}$ and $E$ represent the frequency factor and activation energy, respectively. $R$ and $n$ represent the universal gas constant and the reaction order, respectively. The values of $E$ and $k_{0}$ could be obtained by liner fitting of $\ln t$ with $1 / T$. The relationship between activation energy and carbon conversion is illustrated in Fig. 8. The average activation

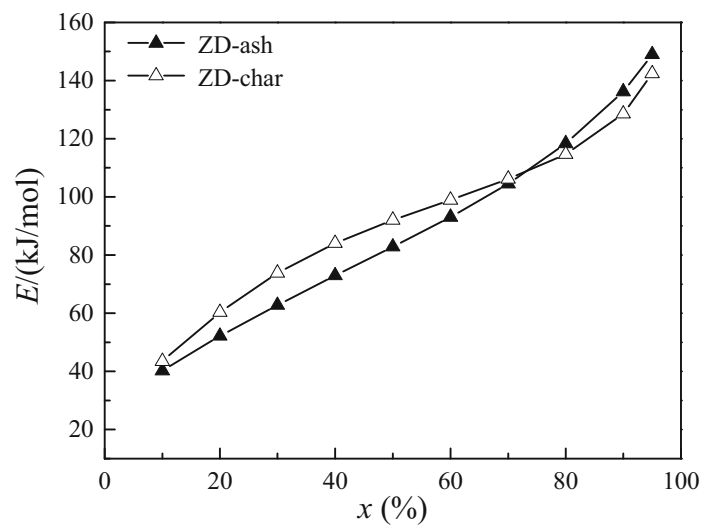

Fig. 8 Comparison of activation energy between ZD char and fly ash energy for ZD char and fly ash is 94.4 and $91.2 \mathrm{~kJ} / \mathrm{mol}$, respectively. As can been seen from Fig. 8, the activation energy of ZD char and fly ash increases with the increase in carbon conversion, but with different increasing amount. When carbon conversion increases from $20 \%$ to $70 \%$, the activation energy of fly ash increases from 40.20 to $104.48 \mathrm{~kJ} / \mathrm{mol}$, and the value is lower than $\mathrm{ZD}$ char. However, when carbon conversion exceeds $70 \%$, the activation energy of fly ash is higher than $\mathrm{ZD}$ char, indicating the lower gasification reactivity of fly ash. Based on ash composition analysis as shown in Table 5, the sodium content in fly ash is higher than in ZD char. The higher sodium content in fly ash is helpful to enhance the conversion of carbon, and hence the activation energy of fly ash is lower during the initial gasification process. With the progress of gasification, more sodium is released to gas phase, and the catalytic effect of sodium in fly ash is decreased. Correspondingly, the higher surface area and abundant microstructure of ZD char play the major role to promote the conversion of carbon. It seems that the gasification reactivity of fly ash is different with the conversion of carbon, and becomes more difficult at higher carbon conversion. So it is meaningful to study the kinetics model of samples especially at higher carbon conversion stage, and this is important for practice application with the purpose to achieve complete conversion of carbon.

Integrated model is an improvement of shrinking core model, which has some meaning in theory and empirics. The equation for integrated model could be given by Eq. (8) (Zou et al. 2007). The logarithm of Eq. (8) could be illustrated by Eq. (9).

$\frac{\mathrm{d} x}{\mathrm{~d} t}=k(1-x)^{n}$

$\ln (d x / d t)=\ln k+n \ln (1-x)$

where $k$ represents the reaction rate constant, and $n$ represents the reaction order.

Figure 9 shows $\ln (\mathrm{d} x / \mathrm{d} t)$ versus $\ln (1-x)$ curve fitted by integrated model at different gasification temperatures. The curves can be divided into two stages. At the initial stage, Ar atmosphere was switched to steam, and maximum reaction rate could be observed. At the second stage, all curves are almost linear. Therefore, we calculate the kinetics parameters ( $n$ and $\ln k$ ) using integrated model at higher carbon conversion stage (40\%-90\%), and the results are summarized in Table 6 . At $900{ }^{\circ} \mathrm{C}$, reaction order of fly ash is close to 1 . It means that $900{ }^{\circ} \mathrm{C}$ gasification of fly ash could be recognized as first order reaction. With the increase of temperature, the reaction order decreases obviously. The results indicate that temperature has great influence on gasification reactivity of fly ash. For ZD char, the reaction order changes slightly at different gasification 

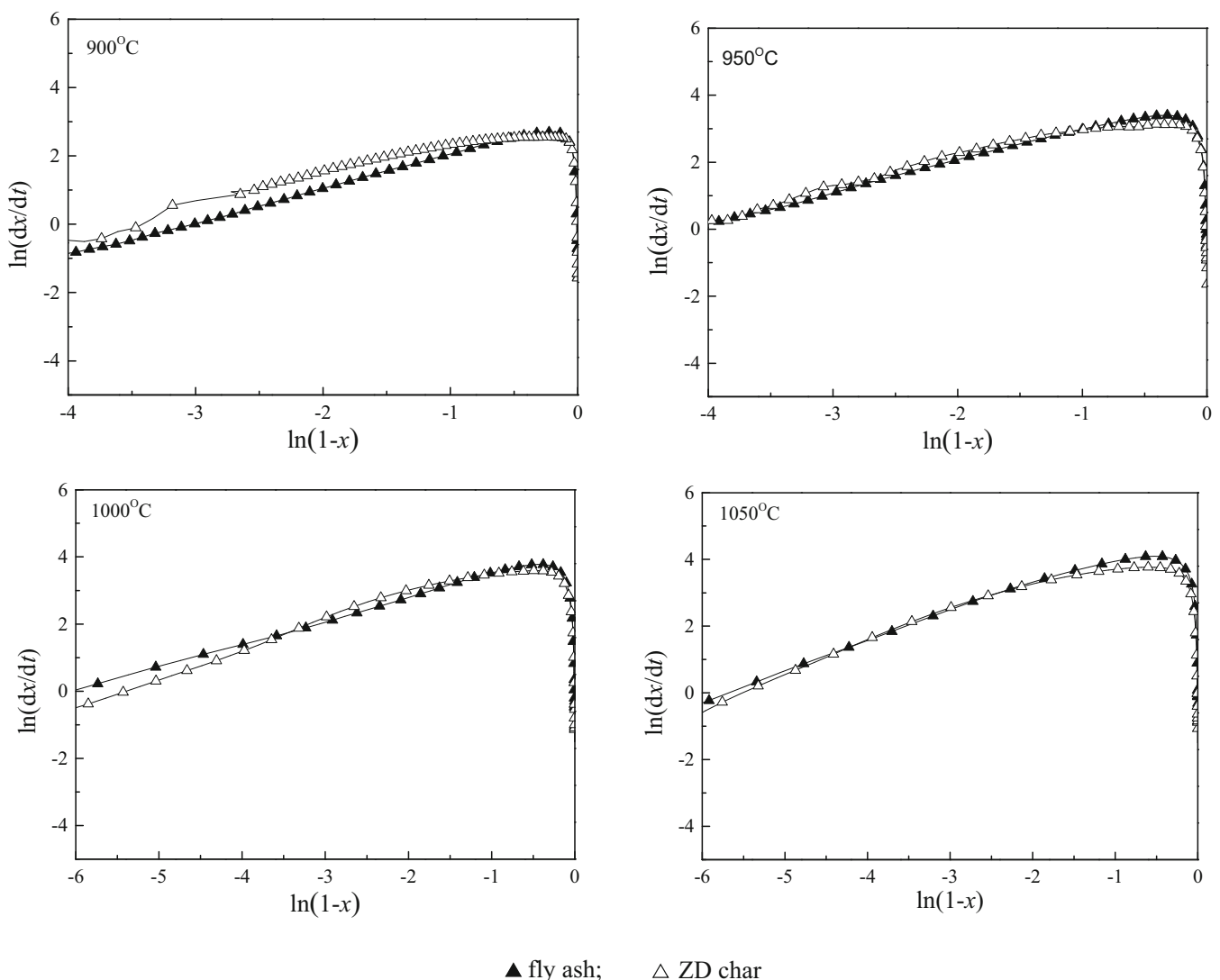

Fig. $9 \ln (\mathrm{dx} / \mathrm{dt})$ versus $\ln (1-x)$ curve fitted by integrated model. Filled triangle: fly ash; open triangle: ZD char

Table 6 Kinetics parameters for fly ash and ZD char

\begin{tabular}{lclll}
\hline Samples & Temperature $\left({ }^{\circ} \mathrm{C}\right)$ & $n$ & $\ln k$ & $R^{2}$ \\
\hline Fly ash & 900 & 1.02 & 3.08 & 0.99 \\
& 950 & 0.93 & 3.92 & 0.99 \\
& 1000 & 0.68 & 4.17 & 0.99 \\
& 1050 & 0.59 & 4.52 & 0.98 \\
ZD char & 900 & 0.73 & 3.02 & 0.98 \\
& 950 & 0.74 & 3.03 & 0.98 \\
& 1000 & 0.73 & 3.02 & 0.98 \\
& 1050 & 0.77 & 4.51 & 0.97 \\
\hline
\end{tabular}

temperatures. The average reaction order of $\mathrm{ZD}$ char is about 0.74 . The results show that integrated model could fit well the curve when carbon conversion is at higher level.

\section{Conclusions}

The gasification reactivity of a high-sodium ZD coal fly ash was studied via a TGA with steam as gasification agent, and the results of fly ash were compared with fast pyrolyzed ZD char. Kinetics data was fitted via DAEM model and integrated model, respectively. Experiments show that increasing temperature accelerates the gasification reactivity of fly ash and ZD char. Probably due to the smaller particle size, the smaller pore diameter and the higher sodium content of fly ash, the reaction rate of fly ash is higher than ZD char at the initial gasification stage. However, the reaction rate of fly ash decreases quickly during the subsequent period. The average activation energy for ZD char and fly ash is $94.4 \mathrm{~kJ} / \mathrm{mol}$ and $91.2 \mathrm{~kJ} / \mathrm{mol}$, respectively. When carbon conversion exceeds $70 \%$, the activation energy of fly ash is higher than $\mathrm{ZD}$ char. Integrated model was used to fit reaction order when carbon conversion increases from $40 \%$ to $90 \%$. The reaction order of $\mathrm{ZD}$ char is about 0.74 , whereas the reaction order of fly ash decreases from 1 about to 0.59 when temperature increase from 900 to $1050{ }^{\circ} \mathrm{C}$. The gasification reactivity of $\mathrm{ZD}$ coal fly ash is quite different with literature results, including pilot scale and commercial scale of CFB gasification fly ash with rarely little catalytic elements in coal ashes. The very different results obtained in this study are related with the unique characteristics of ZD coal fly ash, and also related with the transformation of sodium during gasification process. The experimental and calculation methods are helpful to assess the gasification 
reactivity of high-sodium coal fly ashes. The results obtained in this study would provide useful clue for the high efficient utilization of CFB coal fly ashes.

Acknowledgements This work was financially supported by the National Key R\&D Program of China (No. 2017YFB0602302) and the National Natural Science Foundation of China (No. 21306193).

Open Access This article is distributed under the terms of the Creative Commons Attribution 4.0 International License (http://crea tivecommons.org/licenses/by/4.0/), which permits unrestricted use, distribution, and reproduction in any medium, provided you give appropriate credit to the original author(s) and the source, provide a link to the Creative Commons license, and indicate if changes were made.

\section{References}

Chugh YP, Behum PT (2014) Coal waste management practices in the USA: an overview. Int J Coal Sci Technol 1(2):163-176

Duan W, Yu Q, Liu J, Wu T, Yang F, Qin Q (2016) Experimental and kinetic study of steam gasification of low-rank coal in molten blast furnace slag. Energy 111:859-868

Everson RC, Neomagus HWJP, Kasaini H, Njapha D (2006) Reaction kinetics of pulverized coal-chars derived from inertinite-rich coal discards: gasification with carbon dioxide and steam. Fuel 85(7-8):1076-1082

Fan X, Lu Q, Na Y, Liu Q (2007) Experimental study on coal multigeneration in dual fluidized beds. J Therm Sci 16(3):277-282

Fan S, Yuan Z, Zhao L, Xu L-H, Kang T-J, Kim H-T (2016) Experimental and kinetic study of catalytic steam gasification of low rank coal with an environmentally friendly, inexpensive composite $\mathrm{K}_{2} \mathrm{CO}_{3}$-eggshell derived $\mathrm{CaO}$ catalyst. Fuel 165:397-404

Fu W-B, Wang Q-H (2001) A general relationship between the kinetic parameters for the gasification of coal chars with $\mathrm{CO}$ and coal type. Fuel Process Technol 72(1):63-77

Gonzalo-Tirado C, Jiménez S, Ballester J (2013) Kinetics of $\mathrm{CO}_{2}$ gasification for coals of different ranks under oxy-combustion conditions. Combust Flame 160(2):411-416

Irfan MF, Usman MR, Kusakabe $\mathrm{K}$ (2011) Coal gasification in $\mathrm{CO}_{2}$ atmosphere and its kinetics since 1948: a brief review. Energy 36(1):12-40

Irfan MF, Arami-Niya A, Chakrabarti MH, Wan Daud WMA, Usman MR (2012) Kinetics of gasification of coal, biomass and their blends in air $\left(\mathrm{N}_{2} / \mathrm{O}_{2}\right)$ and different oxy-fuel $\left(\mathrm{O}_{2} / \mathrm{CO}_{2}\right)$ atmospheres. Energy 37(1):665-672

Jin H, Chen Y, Ge Z, Liu S, Ren C, Guo L (2015) Hydrogen production by Zhundong coal gasification in supercritical water. Int J Hydrogen Energy 40(46):16096-16103

Kelebopile L, Sun R, Liao J (2011) Fly ash and coal char reactivity from Thermo-gravimetric (TGA) experiments. Fuel Process Technol 92(6):1178-1186

Kosminski A, Ross DP, Agnew JB (2006) Transformations of sodium during gasification of low-rank coal. Fuel Process Technol 87(11):943-952

Li CZ (2013) Importance of volatile-char interactions during the pyrolysis and gasification of low-rank fuels-a review. Fuel 112:609-623
Li H, Yu Y, Han M, Lei Z (2014) Simulation of coal char gasification using $\mathrm{O}_{2} / \mathrm{CO}_{2}$. Int $\mathrm{J}$ Coal Sci Technol 1(1):81-87

Liu J, Zhu Z, Jiang H, Lu Q, Zhang H (2015) Gasification of bituminous coal in a dual-bed system at different air/coal ratios. Energy Fuels 29(2):496-500

Mi J, Wang N, Wang M, Huo P, Liu D (2015) Investigation on the catalytic effects of AAEM during steam gasification and the resultant char reactivity in oxygen using Shengli lignite at different forms. Int J Coal Sci Technol 2(3):223-231

Quyn D, Wu H, Li CZ (2002) Volatilisation and catalytic effects of alkali and alkaline earth metallic species during the pyrolysis and gasification of Victorian brown coal. Part I. Volatilisation of $\mathrm{Na}$ and $\mathrm{Cl}$ from a set of $\mathrm{NaCl}$ loaded samples. Fuel 81(2):143-149

Song G, Qi X, Song W, Lu Q (2016a) Slagging characteristics of Zhundong coal during circulating fluidized bed gasification. Energy Fuels 30(5):3967-3974

Song W, Song G, Qi X, Lu Q (2016b) Transformation characteristics of sodium in Zhundong coal under circulating fluidized bed gasification. Fuel 182:660-667

Tsadilas C, Samaras V, Evangelou E, Shaheen SM (2014) Influence of fly ash and sewage sludge application on wheat biomass production, nutrients availability, and soil properties. Int J Coal Sci Technol 1(2):221-226

Wang Z, Song Y (2016) Adsorption properties of CFBC ash-cement pastes as compared with PCC fly ash-cement pastes. Int J Coal Sci Technol 3(1):62-67

Wang CA, Jin X, Wang Y, Yan Y, Cui J, Liu Y, Che D (2015) Release and transformation of sodium during pyrolysis of Zhundong coals. Energy Fuels 29(1):78-85

Yu K (2012) Experimental study on coal gasification process in dual circulating fluidized beds. Dissertation. Beijing. Institute of Engineering Thermophysics, Chinese Academy of Sciences

Zhang Y, Zhang H (2017) Gasification characteristics and sodium transformation behavior of high-sodium Zhundong coal. Energy Fuels 31(6):6435-6444

Zhang HX, Zhu ZP, Zhou ZX, Lü QG (2013) Gasification reactivity of fly ash from an industrial fluidized bed gasifier. In: Proceedings of Australian combustion symposium, pp 238-241

Zhang H, Zhu Z, Dong Q, Yu K, Lu Q (2015a) Structural properties and gasification reactivity of Shenmu fly ash obtained from a $5 \mathrm{t} /$ d circulating fluidized bed gasifier. Proc Eng 102:1104-1111

Zhang X, Zhang H, Na Y (2015b) Transformation of sodium during the ashing of Zhundong coal. Proc Eng 102:305-314

Zhang H, Guo X, Zhu Z (2017a) Effect of temperature on gasification performance and sodium transformation of Zhundong coal. Fuel 189:301-311

Zhang H, Liu W, Yu K, Zhu Z, Guo X, Lu Q (2017b) Research on high sodium blended coal gasification in an industrial circulating fluidized bed. J China Coal Soc 42(4):1021-1027

Zhang Y, Zhang H, Zhu Z, Na Y, Lu Q (2017c) Physicochemical properties and gasification reactivity of the ultrafine semi-char derived from a bench-scale fluidized bed gasifier. J Therm Sci 26(4):362-370

Zhou J, Zhuang X, Alastuey A, Querol X, Li J (2010) Geochemistry and mineralogy of coal in the recently explored Zhundong large coal field in the Junggar basin, Xinjiang province, China. Int $\mathrm{J}$ Coal Geol 82(1-2):51-67

Zou JH, Zhou ZJ, Wang FC, Zhang W, Dai ZH, Liu HF, Yu ZH (2007) Modeling reaction kinetics of petroleum coke gasification with $\mathrm{CO}_{2}$. Chem Eng Process 46(7):630-636 